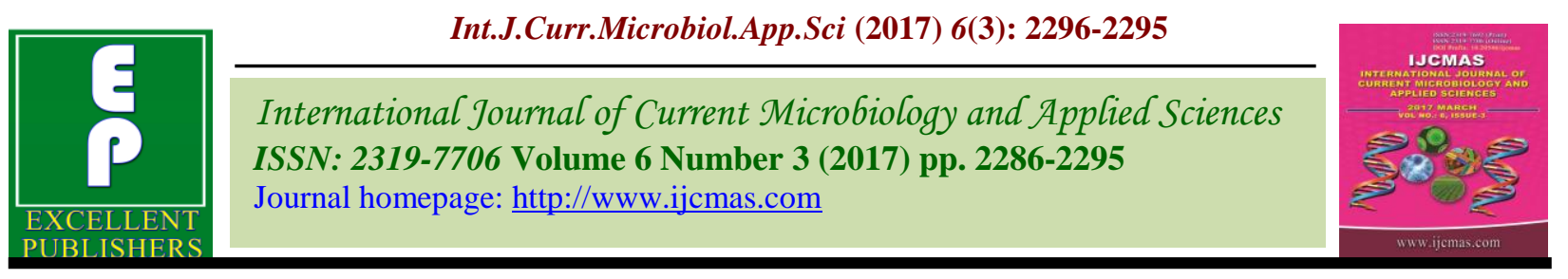

Original Research Article

http://doi.org/10.20546/ijcmas.2017.603.261

\title{
Fixation and Recovery of Applied Potassium in Some Coastal Soils of West Bengal, India
}

\author{
Ranajit Panda ${ }^{1}$ and Sanmay Kumar Patra ${ }^{2}$ \\ ${ }^{1}$ RRS (OAZ), Majhian, D. Dinajpur, UBKV, West Bengal-733133, India \\ ${ }^{2}$ Bidhan Chandra Krishi Viswavidyalaya, Mohanpur, Nadia, West Bengal-741252, India \\ *Corresponding author
}

\begin{tabular}{|c|c|}
\hline & A B S T R A C T \\
\hline $\begin{array}{l}\text { K-reserve, K- } \\
\text { fixation capacity, } \\
\text { K-fertilization. }\end{array}$ & \multirow{3}{*}{$\begin{array}{l}\text { The amount of } \mathrm{K} \text { fixed increased and percent of added } \mathrm{K} \text { fixed of the soils decreased } \\
\text { consistently with increasing rate of } \mathrm{K} \text { application. Maximum percentage of } \mathrm{K} \text { fixation was } \\
\text { occurred at low rate of } \mathrm{K} \text { application and minimum at higher dose of } \mathrm{K} \text { application. The } \\
\text { overall } \mathrm{K} \text { fixation capacity of the soils was moderate. Recovery and fixation rate of } \mathrm{K} \text { per } \\
\text { unit of added } \mathrm{K} \text { in the soils varied from } 0.51 \text { to } 0.73 \text { and } 0.27 \text { to } 0.48 \text {, respectively. The } \\
\text { unit fertilizer } \mathrm{K} \text { requirement per unit increase in soil available } \mathrm{K} \text { ranged from } 1.36 \text { to } 1.94 \text {. } \\
\text { Soils having medium to higher available and } \mathrm{K} \text { reserve with lower } \mathrm{K} \text { fixation and higher } \mathrm{K} \\
\text { recovery need frequent } \mathrm{K} \text { application at lower dose, while soils having poor reserve of } \\
\text { labile and non-labile } \mathrm{K} \text { with moderate to high } \mathrm{K} \text { fixation and lower } \mathrm{K} \text { recovery need } \mathrm{K} \\
\text { fertilization at moderate dose for optimal plant nutrition. }\end{array}$} \\
\hline Article Info & \\
\hline $\begin{array}{l}\text { Accepted: } \\
\text { 24 February } 2017 \\
\text { Available Online: } \\
\text { 10 March } 2017\end{array}$ & \\
\hline
\end{tabular}

\section{Introduction}

Potassium nutrition to plants is more complex than that of nitrogen and phosphorus, because $\mathrm{K}$ occurs in soils in different forms with varying degree of availability. Among different forms of potassium, water soluble and exchangeable $\mathrm{K}$ are considered readily available, non-exchangeable or fixed $\mathrm{K}$ is slowly available and the mineral or structural $\mathrm{K}$ is considered to be the most difficulty available form of potassium. The first two are considered to be the labile pool of $\mathrm{K}$ in supplying $\mathrm{K}$ to plants on short or long-term basis. When the easily available $\mathrm{K}$ is depleted by crop removal or leaching, fixed potassium is released to replenish the labile pool (Subehia et al., 2003; Sood et al., 2008). On the other hand, when the solution and exchangeable pool of $\mathrm{K}$ are low to medium status and are enriched with potassium through K-fertilizers, potassium is likely to be fixed with passage of time.

Potassium fixation in soil is the phenomenon of conversion of labile pool of $\mathrm{K}$ i.e. soil solution and exchangeable $\mathrm{K}$ into moderately or slowly available non-exchangeable $\mathrm{K}$, which is not readily absorbed by the plants (Mortland, 1961). The occurrence of fixation of applied potassium and release of fixed $\mathrm{K}$ plays important role in $\mathrm{K}$ availability to crop plants and response to applied fertilizer K. It is an interlayer phenomenon. More specifically, $\mathrm{K}$ fixation is the result of entrapment of $\mathrm{K}^{+}$ions between the layers of 2:1 minerals especially illite. Normally the release of applied as well as native soil 
potassium and fixation of fertilizer $\mathrm{K}$ in soil occur simultaneously. Soil texture, soil reaction, complementary cations, organic matter content, addition of potassic fertilizers, type of clay minerals and its charge density, degree of interlayering, moisture content, concentration of $\mathrm{K}^{+}$and competing cations including $\mathrm{H}_{3} \mathrm{O}^{+}$are some factors which are regulating/governing the extent of $\mathrm{K}$ fixation in soils (Srinivasa Rao and Khera, 1995; Gurumurthy and Prakasha, 2011). Continuous intensive cropping without potassium administration or sub-optimal application of $\mathrm{K}$ or, unbalanced nutrient usage has resulted in the mining of soil $\mathrm{K}$ which facilitates the $\mathrm{K}$ fixation capacity of soil and simultaneously change the availability trend of applied K.

The study relating to $\mathrm{K}$ fixation thus provides the genuine information on the reaction rates of added $\mathrm{K}$ between different phases of soil $\mathrm{K}$ and the fate of applied fertilizer $K$. This process assumes great importance, because it not only controls the dynamics of different forms of $\mathrm{K}$ in soil, but also indicates the soil potentiality to long-term $\mathrm{K}$ supply to plants. Earlier it was believed that the fixation of applied $\mathrm{K}$ resulted in a drastic reduction of plant available $\mathrm{K}$ and thus becomes main impediment factor in increasing the efficiency of $\mathrm{K}$ fertilizer under the condition of modern intensive agriculture. But later, it has been demonstrated that the fixation of added $\mathrm{K}$ may be beneficial since it conserves the $\mathrm{K}$ nutrient from leaching losses and luxury consumption. Similarly, the fixed K becomes available to subsequent crops over a longer period of time upon depletion of water soluble and exchangeable (Patra and Debnath, 1998). The soils which have high initial K status, the fixation appears to be low and becomes double due to exhaustive cropping (Srinivasa Rao et al., 2000). The variability of K fixation in soil indirectly influences the response of crops to added fertilizer $\mathrm{K}$ and the $\mathrm{K}$ requirement to maintain soil available $\mathrm{K}$ status for optimum plant growth (Chakravorty and Patnaik, 1990). Keeping this in view, the present investigation was undertaken to assess the availability and fixation of added potassium in the surface soils of coastal West Bengal with a view to make a meaningful $\mathrm{K}$ management strategy for higher crop production.

\section{Materials and Methods}

For evaluation of potassium fixation and corresponding $\mathrm{K}$ recovery in the coastal soils under low to high level of fertilizer $\mathrm{K}$ application, a controlled incubation experiment was conducted in the laboratory under alternate wetting and drying conditions as per the procedures outlined by Sahu and Gupta (1987). In this method, $5 \mathrm{~g}$ portions of soil sample in duplicate was taken in a series of $50 \mathrm{ml}$ conical flasks and six doses of $\mathrm{K} @$ $0,10,25,50,100,150$ and $200 \mathrm{mg} \mathrm{K} \mathrm{kg}^{-1}$ soil in the form of reagent grade $\mathrm{KCl}$ solution were added in one ml solution for each gram of soil (soil : solution $=1: 1$ ). The wetted soil samples were allowed to equilibrate for 24 hour at room temperature of $30 \pm 0.5^{\circ} \mathrm{C}$ followed by drying at $70 \pm 0.5^{\circ} \mathrm{C}$ for 24 hour in hot oven (herein after called a cycle). The dried soils after cooling were then rewetted with addition of $5 \mathrm{ml}$ distilled water and subject to another three cycles as before. At the end of incubation period in the drying cycle, available $\mathrm{K}$ of soil was extracted in 25 $\mathrm{ml}$ neutral $1 \mathrm{~N} \mathrm{NH}_{4} \mathrm{OA}_{\mathrm{C}}$ (soil: extractant $=1: 5$ ) by shaking for 5 minutes and then filtered through Whatman No. 41 filter paper. The clear supernatant leachates were analyzed for extractable $\mathrm{K}$ using the flame photometer. The amount of fixed $\mathrm{K}$ of the soil was computed following the equation as below:

$$
\begin{aligned}
& \mathrm{K}_{\text {fixed }}=\mathrm{K}_{\text {applied }} \text { - (Available } \mathrm{K}_{\text {treated- }} \text { Available } \\
& \left.\mathrm{K}_{\text {control }}\right)
\end{aligned}
$$

Where, $\mathrm{K}_{\text {fixed }}=$ amount of added $\mathrm{K}$ fixed, $\mathrm{mg}$ $\mathrm{kg}^{-1}$ soil 
$\mathrm{K}_{\text {applied }}=$ amount of applied $\mathrm{K}, \mathrm{mg} \mathrm{kg}^{-1}$ soil

Available $\mathrm{K}_{\text {treated }}=$ amount of available $\mathrm{K}$ in K-treated soil after incubation, $\mathrm{mg} \mathrm{kg}^{-1}$ soil Available $\mathrm{K}$ control = amount of available $\mathrm{K}$ before incubation, $\mathrm{mg} \mathrm{kg}^{-1}$ soil

\section{Results and Discussion}

\section{Effect of added $\mathrm{K}$ on available $\mathrm{K}$}

The available $\mathrm{K}$ status and the corresponding increase in available $\mathrm{K}$ at different levels of applied $\mathrm{K}$ for the coastal soils of West Bengal are presented in Tables 1 and 2. A perusal of data shows that out of eighteen soil samples under study, one soil viz., Akshyanagar of South 24 Parganas district was low category; eight soils viz., Kalinagar, Narayanpur, Meargheri, Kripakhali, Gosaba, Rudranagar and Kamalpur from South 24 Parganas district and Bholakhali from North 24 Parganas district were medium category and the remaining nine soils from Deuli, Hingalganj, Dhamakhali, Hansnabad, Gobindapur, Potashpur, Hariharpur, Fatepur and Sarda of North 24 Parganas and Medinipur East districts were high category in available $\mathrm{K}$ status as per the proposed rating chart of Dutta et al., (1990). However, irrespective of varying levels of initial available $\mathrm{K}$ reserves and physicochemical characteristics of soils, the available $\mathrm{K}$ content and increase in available $\mathrm{K}$ over control consistently increased with increase in the level of K application. In general, the soils with higher initial available $\mathrm{K}$ status registered the higher availability of $\mathrm{K}$ at graded doses of applied $\mathrm{K}$, whereas the picture was reverse for soils having low to medium level of initial available $\mathrm{K}$ status. Accordingly, nine soils from the districts of North 24 Parganas and Medinipur East with higher available $\mathrm{K}$ and $\mathrm{K}$ reserves recorded the higher increase in available $\mathrm{K}$ in soils with the incremental doses of $\mathrm{K}$ application.
Similarly, eight soils from South and North 24 Parganas districts with medium level of available and $\mathrm{K}$ reserves showed the moderate increase in available $\mathrm{K}$ content with increase in $\mathrm{K}$ application. On the contrary, the lone soil of South 24 Parganas district containing low amounts of available and $\mathrm{K}$ reserves recorded the lower increase in available $\mathrm{K}$ on incremental rate of $\mathrm{K}$ addition. Among the soils, maximum increase in available $\mathrm{K}$ at all levels of added $\mathrm{K}$ was observed in Sarda soil, followed by Fatepur, Hariharpur and Potashpur soils of Medinipur East district, respectively (Table 2). On the other hand, minimum increase in available $\mathrm{K}$ with the increase in level of added $\mathrm{K}$ was recorded in Akshyanagar soil, immediately followed by Kalinagar soil of South 24 Parganas district. The variable increase in available $\mathrm{K}$ in these coastal soils upon addition of incremental doses of applied $\mathrm{K}$ might be due to the differences in the magnitude of initials soil $\mathrm{K}$ status, soil texture, the amount and composition of clay minerals (Sahu and Gupta, 1987; Srinivasa Rao et al., 2000) and the affinity of clay colloids for $\mathrm{K}$ fixation (Patra and Debnath, 1998). The magnitude of recovery rates of $\mathrm{K}$ per unit of added $\mathrm{K}$ in these soils supported the above observation (Table 4).

\section{Effect of added $\mathrm{K}$ on $\mathrm{K}$ fixation}

The amount of $\mathrm{K}$ fixed in coastal soils irrespective of variability of available and non-exchangeable $\mathrm{K}$ status increased with the increase in $\mathrm{K}$ application rate from 10 to $200 \mathrm{mg} / \mathrm{kg}$ soil (Table 3, Fig. 1). These findings thereby suggest that the added $\mathrm{K}$ levels were not adequate enough to determine the greatest $\mathrm{K}$ fixation in these soils. The amounts of $\mathrm{K}$ fixation could still be increased upon addition of higher doses of applied $\mathrm{K}$ beyond $200 \mathrm{mg} / \mathrm{kg}$ soil. This increase in added $\mathrm{K}$ fixed might be attributed to the increase in ionic strength of $\mathrm{K}$ in solution 
resulting in a portion of $\mathrm{K}$ from easily into the inter-lattice position of expanding available labile pool being forced to occupy clay minerals.

Table.1 Available K status (mg/kg) at varied doses of applied K in different soils of the coastal zone of West Bengal

\begin{tabular}{|c|c|c|c|c|c|c|c|}
\hline \multirow{2}{*}{ Location } & \multicolumn{7}{|c|}{ Applied K (mg/kg) } \\
\hline & $\mathbf{0}$ & 10 & 25 & 50 & 100 & 150 & 200 \\
\hline \multicolumn{8}{|c|}{ South 24 Parganas } \\
\hline Akshyanagar & 68.81 & 70.51 & 74.41 & 81.51 & 99.61 & 131.21 & 170.41 \\
\hline Kalinagar & 90.62 & 92.62 & 96.72 & 105.02 & 125.82 & 157.82 & 195.82 \\
\hline Narayanpur & 96.38 & 98.78 & 103.08 & 111.68 & 132.88 & 165.98 & 205.38 \\
\hline Meargheri & 106.72 & 109.22 & 113.52 & 122.42 & 144.02 & 179.02 & 219.12 \\
\hline Kripakhali & 114.78 & 117.38 & 122.38 & 132.38 & 154.48 & 190.08 & 232.58 \\
\hline Gosaba & 153.46 & 156.16 & 161.66 & 172.36 & 195.36 & 232.06 & 276.26 \\
\hline Rudranagar & 168.67 & 171.47 & 177.27 & 188.67 & 212.77 & 250.87 & 295.87 \\
\hline Kamalpur & 174.65 & 177.45 & 183.85 & 195.55 & 220.35 & 258.95 & 304.25 \\
\hline \multicolumn{8}{|c|}{ North 24 Parganas } \\
\hline Bholakhali & 195.63 & 198.63 & 205.73 & 218.03 & 245.73 & 287.73 & 325.83 \\
\hline Deuli & 234.30 & 237.60 & 245.00 & 257.60 & 285.80 & 328.50 & 370.90 \\
\hline Hingalganj & 236.50 & 239.80 & 247.10 & 260.40 & 289.80 & 331.90 & 373.70 \\
\hline Dhamakhali & 240.13 & 243.63 & 251.43 & 264.83 & 295.53 & 337.93 & 376.93 \\
\hline Hasnabad & 248.30 & 251.70 & 260.00 & 272.60 & 303.00 & 345.20 & 387.90 \\
\hline Gobindapur & 252.55 & 256.05 & 264.45 & 278.25 & 308.85 & 353.35 & 392.75 \\
\hline \multicolumn{8}{|c|}{ Medinipur East } \\
\hline Potashpur & 258.75 & 262.25 & 270.85 & 284.75 & 315.95 & 361.65 & 399.95 \\
\hline Hariharpur & 270.36 & 273.96 & 282.66 & 296.76 & 328.96 & 370.26 & 412.16 \\
\hline Fatepur & 284.77 & 288.37 & 297.47 & 311.87 & 344.27 & 385.27 & 427.17 \\
\hline Sarda & 257.55 & 261.25 & 270.45 & 284.95 & 317.35 & 359.25 & 400.95 \\
\hline
\end{tabular}


Table.2 Amount of available K (mg/kg) increase at varied doses of applied $\mathrm{K}$ in different soils of the coastal zone of West Bengal

\begin{tabular}{|c|c|c|c|c|c|c|}
\hline \multirow{2}{*}{ Location } & \multicolumn{6}{|c|}{ Applied K (mg/kg) } \\
\hline & 10 & 25 & 50 & 100 & 150 & 200 \\
\hline \multicolumn{7}{|c|}{ South 24 Parganas } \\
\hline Akshyanagar & 1.7 & 5.6 & 12.7 & 30.8 & 62.4 & 101.6 \\
\hline Kalinagar & 2.0 & 6.1 & 14.4 & 35.2 & 67.2 & 105.2 \\
\hline Narayanpur & 2.4 & 6.7 & 15.3 & 36.5 & 69.6 & 109.0 \\
\hline Meargheri & 2.5 & 6.8 & 15.7 & 37.3 & 72.3 & 112.4 \\
\hline Kripakhali & 2.6 & 7.6 & 17.6 & 39.7 & 75.3 & 117.8 \\
\hline Gosaba & 2.7 & 8.2 & 18.9 & 41.9 & 78.6 & 122.8 \\
\hline Rudranagar & 2.8 & 8.6 & 20.0 & 44.1 & 82.2 & 127.2 \\
\hline Kamalpur & 2.8 & 9.2 & 20.9 & 45.7 & 84.3 & 129.6 \\
\hline \multicolumn{7}{|c|}{ North 24 Parganas } \\
\hline Bholakhali & 3.0 & 10.1 & 22.4 & 50.1 & 92.1 & 130.2 \\
\hline Deuli & 3.3 & 10.7 & 23.3 & 51.5 & 94.2 & 136.6 \\
\hline Hingalganj & 3.3 & 10.6 & 23.9 & 53.3 & 95.4 & 137.2 \\
\hline Dhamakhali & 3.5 & 11.3 & 24.7 & 55.4 & 97.8 & 136.8 \\
\hline Hasnabad & 3.4 & 11.7 & 24.3 & 54.7 & 96.9 & 139.6 \\
\hline Gobindapur & 3.5 & 11.9 & 25.7 & 56.3 & 100.8 & 140.2 \\
\hline \multicolumn{7}{|c|}{ Medinipur East } \\
\hline Potashpur & 3.5 & 12.1 & 26.0 & 57.2 & 102.9 & 141.2 \\
\hline Hariharpur & 3.6 & 12.3 & 26.4 & 58.6 & 99.9 & 141.8 \\
\hline Fatepur & 3.6 & 12.7 & 27.1 & 59.5 & 100.5 & 142.4 \\
\hline Sarda & 3.7 & 12.9 & 27.4 & 59.8 & 101.7 & 143.4 \\
\hline
\end{tabular}


Table.3 Amount of $\mathrm{K}$ fixation $(\mathrm{mg} / \mathrm{kg})$ and per cent $\mathrm{K}$ fixed at different doses of applied $\mathrm{K}$ in different coastal soils of West Bengal

\begin{tabular}{|c|c|c|c|c|c|c|}
\hline \multirow{2}{*}{ Location } & \multicolumn{6}{|c|}{ Applied K (mg/kg) } \\
\hline & 10 & 25 & 50 & 100 & 150 & 200 \\
\hline \multicolumn{7}{|c|}{ South 24 Parganas } \\
\hline Akshyanagar & $\begin{array}{c}8.3 \\
(83.0)\end{array}$ & $\begin{array}{c}19.4 \\
(77.6)\end{array}$ & $\begin{array}{c}37.3 \\
(74.6)\end{array}$ & $\begin{array}{c}69.2 \\
(69.2)\end{array}$ & $\begin{array}{c}87.6 \\
(58.4)\end{array}$ & $\begin{array}{c}98.4 \\
(49.2)\end{array}$ \\
\hline Kalinagar & $\begin{array}{c}8.0 \\
(80.0)\end{array}$ & $\begin{array}{c}18.9 \\
(75.6)\end{array}$ & $\begin{array}{c}35.6 \\
(71.2)\end{array}$ & $\begin{array}{c}64.8 \\
(64.8)\end{array}$ & $\begin{array}{c}82.8 \\
(55.2)\end{array}$ & $\begin{array}{c}94.8 \\
(47.4)\end{array}$ \\
\hline Narayanpur & $\begin{array}{c}7.6 \\
(76.0)\end{array}$ & $\begin{array}{c}18.3 \\
(73.2)\end{array}$ & $\begin{array}{c}34.7 \\
(69.4)\end{array}$ & $\begin{array}{c}63.5 \\
(63.5)\end{array}$ & $\begin{array}{c}80.4 \\
(53.6)\end{array}$ & $\begin{array}{c}91.0 \\
(45.5)\end{array}$ \\
\hline Meargheri & $\begin{array}{c}7.5 \\
(75.0)\end{array}$ & $\begin{array}{c}18.2 \\
(72.8)\end{array}$ & $\begin{array}{c}34.3 \\
(68.6)\end{array}$ & $\begin{array}{c}62.7 \\
(62.7)\end{array}$ & $\begin{array}{c}77.7 \\
(51.8)\end{array}$ & $\begin{array}{c}87.6 \\
(43.8)\end{array}$ \\
\hline Kripakhali & $\begin{array}{c}7.4 \\
(74.0)\end{array}$ & $\begin{array}{c}17.4 \\
(69.6)\end{array}$ & $\begin{array}{c}32.4 \\
(64.8)\end{array}$ & $\begin{array}{c}60.3 \\
(60.3)\end{array}$ & $\begin{array}{c}74.7 \\
(49.8)\end{array}$ & $\begin{array}{c}82.2 \\
(41.1)\end{array}$ \\
\hline Gosaba & $\begin{array}{c}7.3 \\
(73.0)\end{array}$ & $\begin{array}{c}16.8 \\
(67.2)\end{array}$ & $\begin{array}{l}31.1 \\
62.2\end{array}$ & $\begin{array}{c}58.1 \\
(58.1)\end{array}$ & $\begin{array}{c}71.4 \\
(47.6)\end{array}$ & $\begin{array}{l}77.2 \\
38.6\end{array}$ \\
\hline Rudranagar & $\begin{array}{c}7.2 \\
(72.0)\end{array}$ & $\begin{array}{c}16.4 \\
(65.6)\end{array}$ & $\begin{array}{c}30.0 \\
(60.0)\end{array}$ & $\begin{array}{c}55.9 \\
(55.9)\end{array}$ & $\begin{array}{c}67.8 \\
(45.2)\end{array}$ & $\begin{array}{c}72.8 \\
(36.4)\end{array}$ \\
\hline Kamalpur & $\begin{array}{c}7.2 \\
(72.0)\end{array}$ & $\begin{array}{c}15.8 \\
(63.2)\end{array}$ & $\begin{array}{c}29.1 \\
(58.2)\end{array}$ & $\begin{array}{c}54.3 \\
(54.3)\end{array}$ & $\begin{array}{c}65.7 \\
(43.8)\end{array}$ & $\begin{array}{c}70.4 \\
(35.2)\end{array}$ \\
\hline \multicolumn{7}{|c|}{ North 24 Parganas } \\
\hline Bholakhali & $\begin{array}{c}7.0 \\
(70.0)\end{array}$ & $\begin{array}{c}14.9 \\
(59.6)\end{array}$ & $\begin{array}{c}27.6 \\
(55.2)\end{array}$ & $\begin{array}{c}49.9 \\
(49.9)\end{array}$ & $\begin{array}{c}57.9 \\
(38.6)\end{array}$ & $\begin{array}{c}69.8 \\
(34.9)\end{array}$ \\
\hline Deuli & $\begin{array}{c}6.7 \\
(67.0)\end{array}$ & $\begin{array}{c}14.3 \\
(57.2)\end{array}$ & $\begin{array}{c}26.7 \\
(53.4)\end{array}$ & $\begin{array}{c}48.5 \\
(48.5)\end{array}$ & $\begin{array}{c}55.8 \\
(37.2)\end{array}$ & $\begin{array}{c}63.4 \\
(31.7)\end{array}$ \\
\hline Hingalganj & $\begin{array}{c}6.7 \\
(67.0)\end{array}$ & $\begin{array}{c}14.4 \\
(57.6)\end{array}$ & $\begin{array}{c}26.1 \\
(52.2)\end{array}$ & $\begin{array}{c}46.7 \\
(46.7)\end{array}$ & $\begin{array}{c}54.6 \\
(36.4)\end{array}$ & $\begin{array}{c}62.8 \\
(31.4)\end{array}$ \\
\hline Dhamakhali & $\begin{array}{c}6.5 \\
(65.0)\end{array}$ & $\begin{array}{c}13.7 \\
(54.8)\end{array}$ & $\begin{array}{c}25.3 \\
(50.6)\end{array}$ & $\begin{array}{c}44.6 \\
(44.6)\end{array}$ & $\begin{array}{c}52.2 \\
(34.8)\end{array}$ & $\begin{array}{c}63.2 \\
(31.6)\end{array}$ \\
\hline Hasnabad & $\begin{array}{c}6.6 \\
(66.0)\end{array}$ & $\begin{array}{c}13.3 \\
(53.2)\end{array}$ & $\begin{array}{c}25.7 \\
(51.4)\end{array}$ & $\begin{array}{c}45.3 \\
(45.3)\end{array}$ & $\begin{array}{c}53.1 \\
(35.4)\end{array}$ & $\begin{array}{c}60.4 \\
(30.2)\end{array}$ \\
\hline Gobindapur & $\begin{array}{c}6.5 \\
(65.0)\end{array}$ & $\begin{array}{c}13.1 \\
(52.4)\end{array}$ & $\begin{array}{c}24.3 \\
(48.6)\end{array}$ & $\begin{array}{c}43.7 \\
(43.7)\end{array}$ & $\begin{array}{c}49.2 \\
(32.8)\end{array}$ & $\begin{array}{c}59.8 \\
(29.9)\end{array}$ \\
\hline \multicolumn{7}{|c|}{ Medinipur East } \\
\hline Potashpur & $\begin{array}{c}6.5 \\
(65.0)\end{array}$ & $\begin{array}{c}12.9 \\
(51.6)\end{array}$ & $\begin{array}{c}24.0 \\
(48.0)\end{array}$ & $\begin{array}{c}42.8 \\
(42.8)\end{array}$ & $\begin{array}{c}47.1 \\
(31.4)\end{array}$ & $\begin{array}{c}58.8 \\
(29.4)\end{array}$ \\
\hline Hariharpur & $\begin{array}{c}6.4 \\
(64.0)\end{array}$ & $\begin{array}{c}12.7 \\
(50.8)\end{array}$ & $\begin{array}{c}23.6 \\
(47.2)\end{array}$ & $\begin{array}{c}41.4 \\
(41.4)\end{array}$ & $\begin{array}{c}50.1 \\
(33.4)\end{array}$ & $\begin{array}{c}58.2 \\
(29.1)\end{array}$ \\
\hline Fatepur & $\begin{array}{c}6.4 \\
(64.0)\end{array}$ & $\begin{array}{c}12.3 \\
(49.2)\end{array}$ & $\begin{array}{c}22.9 \\
(45.8)\end{array}$ & $\begin{array}{c}40.5 \\
(40.5)\end{array}$ & $\begin{array}{c}49.5 \\
(33.0)\end{array}$ & $\begin{array}{c}57.6 \\
(28.8)\end{array}$ \\
\hline Sarda & $\begin{array}{c}6.3 \\
(63.0)\end{array}$ & $\begin{array}{c}12.1 \\
(48.4)\end{array}$ & $\begin{array}{c}22.6 \\
(45.2)\end{array}$ & $\begin{array}{c}40.2 \\
(40.2)\end{array}$ & $\begin{array}{c}48.3 \\
(32.2)\end{array}$ & $\begin{array}{c}56.6 \\
(28.3)\end{array}$ \\
\hline
\end{tabular}


Table.4 Potassium recovery rate and fixation rate from unit fertilizer K required in the coastal soils of West Bengal

\begin{tabular}{|c|c|c|c|c|}
\hline Location & $\begin{array}{l}\text { Equation connecting } \\
\text { increase in available K } \\
\text { (Y) with added } K(X)\end{array}$ & $\begin{array}{l}\mathrm{K} \\
\text { recovery } \\
\text { rate/unit }\end{array}$ & $\begin{array}{c}\text { K } \\
\text { fixation } \\
\text { rate/unit }\end{array}$ & $\begin{array}{l}\text { Units fertilizer } K \text { rate } \\
\text { required for unit } \\
\text { increase in available } K\end{array}$ \\
\hline \multicolumn{5}{|c|}{ South 24 Parganas } \\
\hline Akshyanagar & 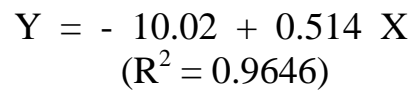 & 0.514 & 0.486 & 1.945 \\
\hline Kalinagar & $\begin{array}{c}Y=-9.43+0.536 X \\
\left(R^{2}=0.9757\right)\end{array}$ & 0.536 & 0.464 & 1.866 \\
\hline Narayanpur & $\begin{array}{c}Y=-9.38+0.553 X \\
\left(R^{2}=0.9752\right)\end{array}$ & 0.553 & 0.447 & 1.808 \\
\hline Meargheri & $\begin{array}{r}Y=-9.78+0.571 X \\
\left(R^{2}=0.9750\right)\end{array}$ & 0.571 & 0.429 & 1.751 \\
\hline Kripakhali & $\begin{array}{c}Y=-9.66+0.595 X \\
\left(R^{2}=0.9760\right)\end{array}$ & 0.595 & 0.405 & 1.681 \\
\hline Gosaba & $\begin{array}{c}Y=-9.74+0.620 X \\
\left(R^{2}=0.9771\right)\end{array}$ & 0.620 & 0.380 & 1.623 \\
\hline Rudranagar & $\begin{array}{c}Y=-9.85+0.643 X \\
\left(R^{2}=0.9791\right)\end{array}$ & 0.643 & 0.357 & 1.555 \\
\hline Kamalpur & $\begin{array}{c}Y=-9.66+0.655 X \\
\left(R^{2}=0.9808\right)\end{array}$ & 0.655 & 0.345 & 1.527 \\
\hline \multicolumn{5}{|c|}{ North 24 Parganas } \\
\hline Bholakhali & $\begin{array}{l}Y=-8.54+0.671 X \\
\left(R^{2}=0.9901\right)\end{array}$ & 0.671 & 0.329 & 1.490 \\
\hline Deuli & $\begin{array}{l}Y=-9.00+0.698 X \\
\left(R^{2}=0.9881\right)\end{array}$ & 0.698 & 0.302 & 1.432 \\
\hline Hingalganj & $\begin{array}{c}Y=-8.76+0.703 X \\
\left(R^{2}=0.9905\right)\end{array}$ & 0.703 & 0.297 & 1.422 \\
\hline Dhamakhali & $\begin{array}{r}Y=-7.90+0.704 X \\
\left(R^{2}=0.9933\right)\end{array}$ & 0.704 & 0.296 & 1.420 \\
\hline Hasnabad & $\begin{array}{r}Y=-8.50+0.713 X \\
\left(R^{2}=0.9906\right)\end{array}$ & 0.713 & 0.287 & 1.402 \\
\hline Gobindapur & $\begin{array}{c}Y=-7.98+0.722 X \\
\left(R^{2}=0.9929\right)\end{array}$ & 0.722 & 0.278 & 1.385 \\
\hline \multicolumn{5}{|c|}{ Medinipur East } \\
\hline Potashpur & $\begin{array}{c}Y=-7.95+0.730 X \\
\left(R^{2}=0.9933\right)\end{array}$ & 0.730 & 0.270 & 1.370 \\
\hline Hariharpur & $\begin{array}{c}Y=-7.56+0.725 X \\
\left(R^{2}=0.9943\right)\end{array}$ & 0.725 & 0.275 & 1.380 \\
\hline Fatepur & $\begin{array}{c}Y=-7.22+0.727 X \\
\left(R^{2}=0.9950\right)\end{array}$ & 0.727 & 0.273 & 1.375 \\
\hline Sarda & $\begin{array}{c}Y=-7.19+0.733 X \\
\left(R^{2}=0.9949\right)\end{array}$ & 0.733 & 0.267 & 1.364 \\
\hline
\end{tabular}


Fig.1 Amount of K fixed at varied doses of applied $\mathrm{K}$ in representative coastal soils

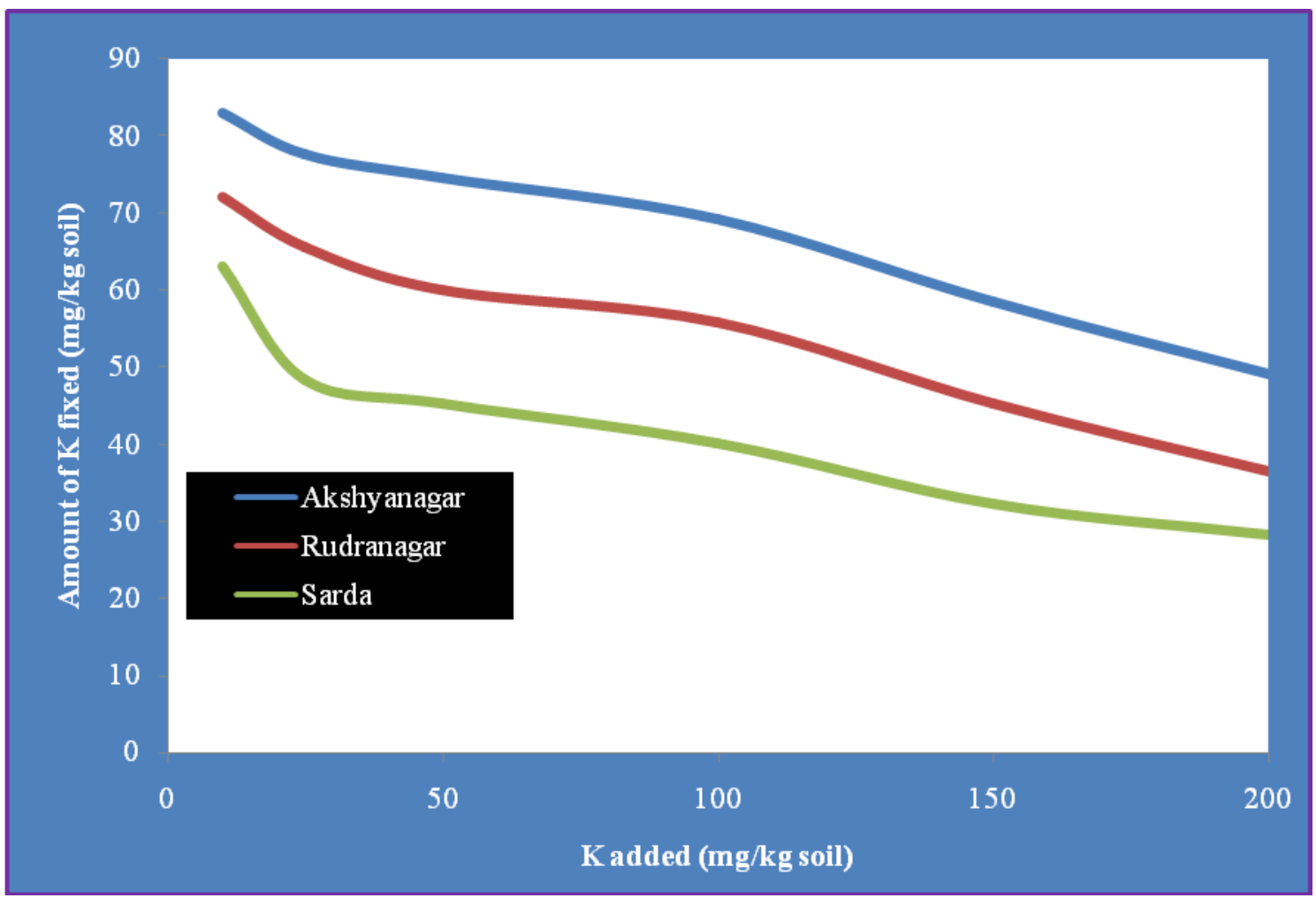

The amount of $\mathrm{K}$ fixation with increase in the level of $\mathrm{K}$ application was, however, variable from soil to soil. The soil from Akshyanagar of South 24 Parganas district with lower amounts of available $\mathrm{K}$ and non-exchangeable $\mathrm{K}$ reserves showed the relatively higher $\mathrm{K}$ fixation to the extent of 8.3 to $98.4 \mathrm{mg} / \mathrm{kg}$ soil upon addition of different rates of $\mathrm{K}$. Similarly, eight soils from Kalinagar, Narayanpur, Meargheri, Kripakhali, Gosaba, Rudranagar and Kamalpur of the South 24 Parganas district and from Bholakhali of North 24 Parganas district containing medium levels of available and reserve $\mathrm{K}$ recorded the moderate $\mathrm{K}$ fixation ranging from 7.0 to 94.8 $\mathrm{mg} / \mathrm{kg}$ soil. On the other hand, the remaining nine soils from the districts of North 24 Parganas and Medinipur East with higher initial available $\mathrm{K}$ and reserves $\mathrm{K}$ recorded relatively the lower K fixation by 6.3 to 63.4 $\mathrm{mg} / \mathrm{kg}$ soil with addition of graded levels of $\mathrm{K}$. These differences in K fixation in the soils might be due to the variations in soil texture, the quantity and composition of clay minerals, native soil $\mathrm{K}$ status and $\mathrm{K}$ saturation of the inner lattice of micaceous minerals (Patra and Debnath 1998; Singh et al., 1999). Contrary to this, the percent of added $\mathrm{K}$ fixed decreased progressively with increasing rate of $\mathrm{K}$ administration (Table 3). However, maximum percentage of $\mathrm{K}$ fixation was observed at low level of $\mathrm{K}$ application (10 $\mathrm{mg} \mathrm{K} / \mathrm{kg}$ soil) in all the soils, the more so in the $\mathrm{K}$ depleted soils having relatively lesser amount of available $\mathrm{K}$ and reserve $\mathrm{K}$. The reverse was true for soils having higher $\mathrm{K}$-enrichment in terms of available $\mathrm{K}$ and reserve $\mathrm{K}$. However, upon incorporation of graded levels of soluble $\mathrm{K}$, the magnitude of $\mathrm{K}$ fixed in these soils gradually decreased. This effect was more pronounced in high K-reserve soils, immediately followed by moderate K-reserve soils and the least in low K-reserve soils. This could be attributed to the gradual saturation of the $\mathrm{K}$ fixing sites due to the addition of higher doses of fertilizer $\mathrm{K}$ in these soils (Singh et 
al., 1999). Similar observation have been reported earlier by Sahu and Gupta (1987) and Srinivasa Rao et al., 2000) in different soil types of India. It is presumed that the mechanism of $\mathrm{K}$ fixation is preceded by the moving the $\mathrm{K}$ ions from the edge and surface to the interior of the soil mineral fabric and increasing amount of $\mathrm{K}$ application might have influenced the ion diffusion (Chakravorty and Patnaik, 1990).

\section{Unit fertilizer $\mathrm{K}$ requirement}

The regression equation showing the relationship of increase in available $\mathrm{K}(\mathrm{Y})$ with varied levels of added $\mathrm{K}(\mathrm{X})$ for the coastal soils are furnished in Table 4. The analysis of data showed that the recovery rate of $\mathrm{K}$ per unit of added $\mathrm{K}$ varied within the limit of 0.514 to 0.733 . In general, the higher recovery rate of $\mathrm{K}$ was observed in nine soils of high $\mathrm{K}$ category exclusively in the domains of North 24 Parganas and Medinipur East districts, followed by eight soils of medium category under South and North 24 Parganas districts showing moderate $\mathrm{K}$ recovery rate and the lower $\mathrm{K}$ recovery rate with added $\mathrm{K}$ in the lone soil of low category of South 24 Parganas district. Irrespective of the variability soil characteristics and forms of $\mathrm{K}$, the higher value of 0.733 was demonstrated by Sarda soil of Medinipur East, whereas the lower value was obtained by Akshyanagar soil of South 24 Parganas district. On the other hand, the calculated rate of $\mathrm{K}$ fixation per unit of added $\mathrm{K}$ was found to be just opposite to the $\mathrm{K}$ recovery rate per unit of added $\mathrm{K}$ and this is obvious. Accordingly, the highest $\mathrm{K}$ fixation rate of 0.486 per unit of applied K was recorded in Akshyanagar soil and the lowest of 0.267 in Sarda soil. Based on slope values of regression equations, the unit fertilizer $\mathrm{K}$ requirement per unit increase in available $\mathrm{K}$ in soil was calculated and the value was relatively higher for the K-depleted soil of Akshyanagar, moderate for eight soils from Kalinagar, Narayanpur, Meargheri, Kripakhali, Gosaba, Rudranagar, Kamalpur of the South 24 Parganas district and Bholakhali of North 24 Parganas district having medium range of available $K$ and reserve $K$ and the lower in the remaining nine soils from the districts of North 24 Parganas and Medinipur East with higher available $\mathrm{K}$ and reserves $\mathrm{K}$ (Table 3). However, the highest unit fertilizer $\mathrm{K}$ requirement per unit increase in available $\mathrm{K}$ was observed to be the highest in Akshyanagar soil and the lowest in Sarda soil. These values irrespective of soils, on an average, varied from 1.364 to 1.945 .

The results of the present study indicates that these coastal soils have varying $\mathrm{K}$ fixation and $\mathrm{K}$ recovery rate presumably depending upon the soil texture, soil mineralogy, labile and non-labile $\mathrm{K}$ reserves and above all, external administration of fertilizer $\mathrm{K}$. The soils having relatively medium and higher amounts of available $\mathrm{K}$ and reserves $\mathrm{K}$ showed lower $\mathrm{K}$ fixation and higher $\mathrm{K}$ recovery rate and thus need frequent $\mathrm{K}$ application at lower doses to meet $\mathrm{K}$ requirement of crops. Similarly, the soil having poor reserve of labile and non-labile pool of $\mathrm{K}$ showed relatively moderate to high $\mathrm{K}$ fixation and lower $\mathrm{K}$ recovery rate and hence need $\mathrm{K}$ fertilizer application at moderate to high doses for mitigating optimal plant nutrition. In addition, regular monitoring on the changes of available $\mathrm{K}$ and reserves $\mathrm{K}$ in these coastal soils under intensive cropping is also imperative for meaningful $K$ management strategy for sustainable crop production.

\section{References}

Chakraborty, P. and Patnaik, S. 1990. Fixation and release of potassium in flooded rice soils. J. Indian Soc. Soil Sci., 38: 243-247. 
Gurumurthy, K.T. and Prakasha, H.C. 2011. Potassium fixation capacity of surface soils under different land use systems. $J$. Indian Soc. Soil Sci., 59(2): 185-187.

Mortland, M.M. 1961. The dynamics character of potassium release and fixation. Soil Sci., 91: 11-13.

Patra, S.K. and Debnath, A. 1998. Potassium fixation and releasing power of Tarai acid soils of West Bengal. J. Pot. Res., 15: 109-114.

Sahu, S. and Gupta, S.K. 1987. Fixation and release of potassium in some alluvial soils. J. Indian Soc. Soil Sci., 35(1): 2934.

Sahu, S. and Gupta, S.K. 1988. Forms of potassium in some soils under forest cover. Indian Agric., 32(1): 23-29.

Singh, S. P., Ram, J. and Singh, N. 1999. Dynamics of potassium as influenced by moisture and fertilizer regimes in some soils of Nagaland. J. Pot. Res., 15(1-4): 48-53.

Sood, B., Subehia, S.K. and Sharma, S.P. 2008. Potassium fractions in acid soil continuously fertilized with mineral fertilizers and amendments under maize-wheat cropping systems. $J$. Indian Soc. Soil Sci.. 56(1): 54-58.

Srinivasarao, Ch. and Khera, M.S. 1995. Fixation of added potassium and fertilizer $\mathrm{K}$ requirements of illite dominant soils as affected by $\mathrm{K}$ depletion. J. Indian Soc. Soil Sci., 43(3): 405-407.

Srinivasarao, Ch. and Khera, M.S. 1996. Response to potassium in K-depleted Ustochrepts in relation to $\mathrm{K}$ fixation. $J$. Pot. Res., 2(4): 351-357.

Srinivasarao, Ch., Rupa, T.R., Rao, A.S. and Bansal, S.K. 2000. Potassium fixation characteristics of major Benchmark soils of India. J. Indian Soc. Soil Sci., 48(2): 220-228.

Subehia, S.K., Brij Lal and Sharma, S.P. 2003. Relationship of forms of potassium with its uptake by potato crop in mid hill soils of Himachal Pradesh. $J$. Pot. Res., 19: 99-102.

\section{How to cite this article:}

Ranajit Panda and Sanmay Kumar Patra. 2017. Fixation and Recovery of Applied Potassium in Some Coastal Soils of West Bengal. Int.J.Curr.Microbiol.App.Sci. 6(3): 2286-2295. doi: http://doi.org/10.20546/ijcmas.2017.603.261 